\title{
LOW-INTENSITY ENDURANCE TRAINING AND RIGHT VENTRICULAR MYOCYTES OF HYPERTENSIVE RATS
}

\author{
TREINAMENTO AERÓBIO DE BAIXA INTENSIDADE EMIÓCITOS DO VENTRÍCULO DIREITO \\ DE RATOS HIPERTENSOS
}

Original Article

ARTIGO ORIGINAL

Artículo Original

\author{
ENTRENAMIENTO DE RESISTENCIA DE BAJA INTENSIDAD Y MIOCITOS DEL VENTRÍCULO DERECHO \\ DERATAS HIPERTENSAS
}

\begin{abstract}
Miguel Araujo Carneiro-Júnior 1,2 (Physical Education Professional) Thales Nicolau Prímola-Gomes (Physical Education Professional) Judson Foseca Quintão-Júnior (Physical Education Professional) Lucas Rios Drummond' (Physical Education Professional) Victor Neiva Lavorato' (Physical Education Professional)

Filipe Rios Drummond'

(Physical Education Professional)

Leonardo Bonato Felix

(Electrical Engineer)

Edilamar Menezes de Oliveira ${ }^{4}$

(Pharmacist)

José Geraldo Mill²

(Physician)

Antonio José Natali

(Physical Education Professional)
\end{abstract}

1. Universidade Federal de Viçosa (UFV), Department of Physical Education, Laboratory of Exercise Biology, Viçosa, Minas Gerais, MG, Brazil.

2. Universidade Federal do Espírito Santo (UFES), Department of Physiological Sciences, Vitória, Espírito Santo, ES, Brazil. 3. Universidade Federal de Viçosa (UFV), Department of Electrical Engineering, Viçosa, Minas Gerais, $M G$, Brazil.

4. Universidade de São Paulo (USP) School of Physical Education and Sport, Laboratory of Biochemistry and Molecular Biology of the Exercise, São Paulo, SP, Brazil.

\section{Correspondence:}

Miguel Araujo Carneiro-Júnior Universidade Federal de Viçosa (UFV), Department of Physical Education. Av. Peter Henry Rolfs, s/n, Viçosa, Minas Gerais, MG. Brazil. 36570-000.miquel.junior@ufv.br

\begin{abstract}
Introduction: The structural and mechanical adaptations of the right ventricular (RV) myocytes in response to hypertension associated with low-intensity endurance training (LIET) have not been studied in experimental models. Objective: To determine the effects of LIET on the structural and mechanical properties of RV myocytes in spontaneously hypertensive rats (SHRs). Methods: Male SHRs and normotensive Wistar rats (age: 16 weeks) were allocated to groups ( $n=7$ ): WIS (Wistar Controls); SHR-C (SHR Controls) and SHR-T (SHR Trained; $60 \mathrm{~min} /$ day, 50-60\% of maximal exercise capacity, 5 days/week for 8 weeks). Systolic arterial pressure (SAP), isolated RV myocyte dimensions, contractility, intracellular $\mathrm{Ca}^{2+}$ transient $\left(\left[\mathrm{Ca}^{2+}\right]\right.$ ), and ventricular $\mathrm{Ca}^{2+}$ regulatory proteins were measured. The statistical analysis was performed by one-way ANOVA followed by the Tukey post hoc test $(a=5 \%)$. Results: LIET reduced the SAP in SHR animals (SHR-C, $164 \pm 2 \mathrm{mmHg}$ vs. SHR-T, $152 \pm 4 \mathrm{mmHg}$; $P<0.05$ ). Hypertension increased cell length (WIS, 156.8 $\pm 2.7 \mu \mathrm{m} ;$ SHR-C, $166.6 \pm 3.1 \mu \mathrm{m} ; \mathrm{P}<0.05)$ but did not affect cell width or volume ( $>0.05)$. LIET did not change the cell dimensions in the SHR-T. Neither hypertension nor LIET affected myocyte contractility or the expression of $\mathrm{Ca}^{2+}$ regulatory proteins in the RV of the SHR-C and SHR-T groups. Hypertension did not affect the amplitude of the $\left[\mathrm{Ca}^{2+}\right]_{i}$ transient or the time to half resting level ( $P>0.05$ ), but increased the time to peak (WIS, $58 \pm 1 \mathrm{msvs}$. SHR-C, $79 \pm 2 \mathrm{~ms}$; $P<0.05)$. LIET increased the amplitude of the $\left[\mathrm{Ca}^{2+}\right]_{i}$ transient $\left(\mathrm{WIS}, 2.28 \pm 0.07 \mathrm{~F} / \mathrm{F}_{0}\right.$ and $\mathrm{SHR}-\mathrm{C}, 2.48 \pm 0.08 \mathrm{~F} / \mathrm{F}_{0} \mathrm{Vs}$. SHR-T, $2.87 \pm 0.08 \mathrm{~F} / \mathrm{F}_{0} \mathrm{P}<0.05$ ), but did not alter the times to peak or to half resting level. Conclusion: LIET had no effect on the structural and mechanical properties of RV myocytes in the SHRs, although it increased the amplitude of the $\left[\mathrm{Ca}^{2+}\right]$ i transient and reduced the SAP. Level of evidence I, Therapeutic Studies - Investigating the Results of Treatment.
\end{abstract}

Keywords: Exercise; Rats; Hypertension; Heart.

\section{RESUMO}

Introdução: As adaptações estruturais e mecânicas de miócitos do ventrículo direito (VD) em resposta à hipertensão associada ao treinamento aeróbio de baixa intensidade (TABI) não foram estudadas em modelos experimentais de ratos. Objetivo: Determinar os efeitos do TABI sobre as propriedades estruturais e mecânicas de miócitos do VD em ratos espontaneamente hipertensos (SHR). Métodos: Ratos SHR e ratos Wistar machos e normotensos (idade: 16 semanas) foram distribuídos em grupos ( $n=7$ ): WIS (Wistar controle); SHR-C (SHR controle) e SHR-T (SHR treinados; 60 min/dia, 50\% a 60\% da capacidade máxima de exercício, 5 dias/semana por 8 semanas). Procedeu-se à medição de pressão arterial sistólica (PAS), dimensões dos miócitos isolados do VD, contratilidade, transiente intracelular de $\mathrm{Ca}^{2+}\left(\left[\mathrm{Ca}^{2+}\right]_{j}\right)$ e de proteínas reguladoras de $\mathrm{Ca}^{2+}$. A análise estatística foi realizada por ANOVA one-way, seguida por teste de Tukey post hoc $(a=5 \%)$. Resultados: O TABI reduziu a PAS nos animais SHR (SHR-C, $164 \pm 2 \mathrm{mmHg}$ vs. SHR-T, $152 \pm 4 \mathrm{mmHg} ; P<$ 0,05). A hipertensão aumentou o comprimento celular (WIS, 156,8 $\pm 2,7 \mu \mathrm{m} ;$ SHR-C, 166,6 $\pm 3,1 \mu \mathrm{m} ; \mathrm{P}<0,05$ ), mas não afetou a largura ou o volume $(P>0,05)$. OTABI não alterou as dimensões celulares nos SHR-T. Nem a hipertensão nem o TABI afetaram a contratilidade dos miócitos ou a expressão das proteínas reguladoras do $\mathrm{Ca}^{2+}$ no VD dos grupos SHR-C eSHR-T. A hipertensão não afetou a amplitude do transiente de $\left[\mathrm{Ca}^{2+}\right]_{i}$ e o tempo até a metade do nível de repouso $(P>$ $0,05)$, mas aumentou o tempo até o pico (WIS, $58 \pm 1 \mathrm{msvs}$. SHR-C, $79 \pm 2 \mathrm{~ms} ; P<0,05)$. O TABl aumentou a amplitude do transiente de $\left[\mathrm{Ca}^{2+}\right]_{i}\left(W I S, 2,28 \pm 0,07 \mathrm{~F} / \mathrm{F}_{0}\right.$ e SHR-C, 2,48 $\pm 0,08 \mathrm{~F} / \mathrm{F}_{0} v \mathrm{Vs}$. SHR-T, 2,87 $\left.\pm 0,08 \mathrm{~F} / \mathrm{F}_{0} P<0,05\right)$, mas não alterou os tempos atéo pico e a metade do nível de repouso. Conclusão: OTABI não teve efeito sobre as propriedades estruturais e mecânicas de miócitos do VD de SHR, embora tenha aumentado a amplitude do transiente de $\left[\mathrm{Ca}^{2+}\right]_{i}$ e reduzido a PAS. Nível de evidência l, Estudos terapêuticos - Investigação dos resultados do tratamento.

Descritores: Exercício; Ratos; Hipertensão; Coração.

\section{RESUMEN}

Introducción: Las adaptaciones estructurales y mecánicas de los miocitos del ventrículo derecho (VD) en respuesta a la hipertensión asociada al entrenamiento de resistencia de baja intensidad (ERBI) no se han estudiado en modelos experimentales de ratas. Objetivo: Determinar los efectos del ERBI sobre las propiedades estructurales y mecánicas de los miocitos del VD en ratas espontáneamente hipertensas (SHR). Métodos: Ratas SHR y ratas Wistar machos y normotensas (edad: 16 semanas) fueron distribuidas en grupos ( $n=7)$ : WIS (Wistar controle); SHR-C (SHR 
controle) y SHR-T(SHR entrenado; $60 \mathrm{~min} /$ día, el 50\% a 60\% de la capacidad máxima de ejercicio, 5 días/semana por 8 semanas). Se midieron presión arterial sistólica (PAS), dimensiones de los miocitos aislados del VD, contractilidad, transitorio intracelular de $\mathrm{Ca}^{2+}\left(\left[\mathrm{Ca}^{2+}\right]_{i}\right)$ y proteínas reguladoras de $\mathrm{Ca}^{2+}$. El análisis estadístico se realizó mediante ANOVA one-way seguida por la prueba de Tukey post hoc $(a=5 \%)$. Resultados: El ERBI redujo la PAS en los animales SHR (SHR-C, $164 \pm 2 \mathrm{mmHg}$ contra SHR-T $152 \pm 4 \mathrm{mmHg}, P<0,05)$. La hipertensión aumentó la longitud de la célula (WIS, 156,8 $\pm 2,7 \mu m, S H R-C, 166,6 \pm 3,1 \mu m ; P<0,05)$, pero no afectó el ancho o el volumen (P>0,05). El ERBI no alteró las dimensiones de la célula en SHR-T. Ni la hipertensión y ni el ERBI afectaron la contractilidad de los miocitos o la expresión de proteínas reguladoras de C $\mathrm{Ca}^{2+}$ en el VD de los grupos SHR-Cy SHR-T. La hipertensión no afectó la amplitud del transitorio de $\left[\mathrm{Ca}^{2+}\right]_{i}$ y el tiempo hasta la mitad del nivel de reposo $(P>0,05)$, pero aumentó tiempo hasta el pico (WIS, $58 \pm 1 \mathrm{~ms}$ contra SHR-C, $79 \pm 2 \mathrm{~ms} ; \mathrm{P}<0,05)$. EI ERBI aumentó la amplitud del transitorio de $\left[\mathrm{Ca}^{2+}\right]_{i}(\mathrm{WIS}, 2,28 \pm$ $0,07 \mathrm{~F} / \mathrm{F}_{0}$ y SHR-C, 2,48 $\pm 0,08 \mathrm{~F} / \mathrm{F}_{0}$ contra $\left.S H R-T, 2,87 \pm 0,08 \mathrm{~F} / \mathrm{F}_{0} P<0,05\right)$, pero no alteró los tiempos hasta el pico y la mitad del nivel de reposo. Conclusión: EI ERBI no tuvo efecto sobre las propiedades estructurales y mecánicas de los miocitos del VD de SHR, aunque aumentó la amplitud del transitorio de $\left[\mathrm{Ca}^{2+}\right]_{i}$ y redujo la PAS. Nivel de Evidencia I,

Estudios terapéuticos - Investigación de los resultados del tratamiento.

Descriptores: Ejercicio; Ratas; Hipertensión; Corazón.

\section{INTRODUCTION}

Hypertension is the leading risk factor for cardiovascular disease and a precursor of heart failure thus producing major concern to public health authorities. ${ }^{1}$ Hypertension impacts negatively the myocardial structure and function leading to systolic and diastolic impairment, mainly in the left ventricle. ${ }^{2}$

The spontaneously hypertensive rat (SHR) is a well-established model of genetic hypertension. Young (4 months) SHR show a compensated cardiac state and in spite of presence of severe myocardial hypertrophy, the left ventricle pump function is preserved until the age of 12 months. However, severe cardiac dysfunctions develop thereafter and presence of heart failure is reported at the age between 18 and 24 months. ${ }^{3}$ In the compensated phase of hypertension in SHR, it has been reported that the left ventricular (LV) myocyte shortening increases, whereas the action potential duration and the time course of intracellular global $\mathrm{Ca}^{2+}\left(\left[\mathrm{Ca}^{2+}\right]_{\mathrm{i}}\right)$ transient, cell shortening and relaxation are prolonged..$^{4-8}$

Preservation of cardiac functioning can be obtained by several interventions in hypertension, like the anti-hypertensive therapy, a healthy diet, smoking cessation, being exercise training an important hypotensive non-pharmacological therapeutic strategy. ${ }^{1,9-12}$ The recommended low-intensity exercise training (LIET) improves LV inotropic e lusitropic performance, $\beta$-adrenergic responsiveness, phosphorylation of $\left[\mathrm{Ca}^{2+}\right]_{i}$ regulatory proteins, and attenuates systolic dysfunction in the compensatory phase of hypertension in female SHRs. ${ }^{13,14}$ Most of these studies have been concentrated in the left ventricle myocardium while little is known about the effects of hypertension and LIET in the right ventricle.

It is important to point out that overall cardiac performance depends on the simultaneous and synchronous activity of both ventricles. ${ }^{15}$ Right ventricle function is also an important prognostic marker in conditions that have traditionally been regarded as primarily LV pathologic conditions, such as congestive heart failure and acute myocardial infarction. ${ }^{16,17}$ Right ventricle works as a barometer of cardiovascular symptoms, once its function represents the interaction between afterload (e.g., increased LV filling pressures) and right ventricular (RV) contractile reserve. ${ }^{18}$ Therefore, hypertension could also affect the RV, mainly by the increased sympathetic activity in both ventricles. ${ }^{19}$

Chronic changes produced in the heart due to endurance training are secondary to cardiomyocyte adaptations. Previous studies have shown that aerobic training improves the contractile function of single LV cardiomyocytes of normotensive rats. ${ }^{8,20-22}$ However, no adaptations in the RV myocytes were observed. ${ }^{23}$ LIET is shown to induce morphological and functional beneficial effects to left ventricular cardiomyocytes of $\mathrm{SHR}^{6-8}$. Nevertheless, the structural and mechanical adaptations of the RV myocytes in response to hypertension associated to LIET have not been studied in experimental models, and this could contribute to a better characterization of regional cellular phenotypes of exercise-induce cardiac remodeling in hypertensive hearts.

Therefore, the objective of the present study was to verify the effects of LIET on structural and mechanical properties of RV myocytes in SHRs.

\section{MATERIALS AND METHODS}

Male SHR and Wistar rats (four month old) were housed in collective cages under a 12-12 h light/dark cycle in a temperature controlled room $\left(22^{\circ} \mathrm{C}\right)$ with free access to water and standard diet. A group of SHR were randomly assigned to exercise. Thus, the following groups were studied: WIS (Wistar normotensive control rats, $n=7$ ), SHR-C (hypertensive control rats, $n=7$ ) and SHR-T (hypertensive rats trained for eight weeks, $n=7$ ). The experimental protocols were approved by the Ethics Committee for Animal Use at the Federal University of Viçosa (Protocol \#48/2011).

Exercise training was performed on a motor-driven treadmill (Insight Equipamentos Científicos, Brazil), 60 min/day, 5 days per week, for 8 weeks. Before beginning the exercise training program, all animals were placed on the treadmill for adaptation ( $10 \mathrm{~min} /$ day, $0 \%$ grade, $0.3 \mathrm{~km} / \mathrm{h}, 5$ days). Two days after the last exercise session, all animals were subjected to a running test to determine the maximal running speed (MRS). The training intensity throughout the training period was progressively increased, which reached $1 \mathrm{~h} /$ day, $0 \%$ grade, at 50-60\% of MRS on the third week. ${ }^{8}$ The MRS test was repeated at the end of the $4^{\text {th }}$ week of training in the animals of the SHR-T group to update the training intensity. Two days after the last training session, the MRS test was repeated in all animals to evaluate their total exercise time until fatigue (TTF). The animals from the WIS and SHR-C groups were handled every day (5-10 min, $0 \%$ grade, 0.3 km/h, 3 days/week).

The body weight (BW) of all rats was measured every week, and the resting heart rate (RHR) and the systolic arterial pressure (SAP) were recorded before beginning and 2 days after the last exercise session using a tail-cuff method (PowerLab 4/30, ADInstruments, USA).

Two days after the last MRS test, the rats were weighed and then sacrificed by cervical dislocation. The hearts were quickly removed and mounted on a Langendorff system and perfused for $\sim 5$ min with a modified Hepes-Tyrode solution with the following composition (in $\mathrm{mM}$ ): $130 \mathrm{NaCl}, 1.43 \mathrm{MgCl}_{2}, 5.4 \mathrm{KCl}, 0.75 \mathrm{CaCl}_{2}, 5$ Hepes, 10 glucose, 20 taurine and 10 creatine, $\mathrm{pH} 7.3$ at $37{ }^{\circ} \mathrm{C}$. The perfusion solution was changed to 
a calcium-free solution containing EGTA $(0.1 \mathrm{mM})$ for $6 \mathrm{~min}$, and after that, hearts were perfused for 15-20 min with a solution containing 1 $\mathrm{mg} / \mathrm{ml}$ collagenase type II (Worthington, USA). The digested heart was removed from the apparatus, the ventricles and the right ventricle were carefully isolated and weighed. The right ventricle was cut into small pieces and placed in conical flasks with collagenase-containing solution supplemented with 1\% bovine serum albumin (Sigma-Aldrich, Saint Louis, MO, USA). The cells were dispersed by agitating the flasks for periods of $5 \mathrm{~min}$ at $37^{\circ} \mathrm{C}$, and were separated from the non-dispersed tissue by filtration and stored at $\sim 5^{\circ} \mathrm{C}$ until needed. Only the calcium-tolerant, quiescent, rod-shaped cardiomyocytes showing clear cross striations were studied, within 2-3 h after isolation.

The isolated cardiomyocytes were placed in a chamber mounted on the stage of an inverted microscope (Nikon Eclipse, TS100, USA). The chamber was perfused with Hepes-Tyrode solution at room temperature. Steady-state $1 \mathrm{~Hz}$ contractions were elicited via platinum bath electrodes (Myopacer, Field Stimulator, lonoptix, USA) with 5 ms voltage pulses with an intensity of $20 \mathrm{~V}$. The cells were visualized on a PC monitor with a NTSC camera (Myocam, lonoptix, USA). This image was used to measure cell shortening in response to electrical stimulation using a video motion edge detector (lonWizard, lonoptix, USA). Cell shortening (expressed as a percentage of resting cell length) and maximal velocity of contraction and relaxation were calculated. The cell image was used to determine the measurements of resting cell length and midpoint width, which were used to calculate the cell volume as previously described., 7,24

Isolated cardiomyocytes from the right ventricle were loaded with fluo-4 AM, membrane-permeant form of the $\mathrm{Ca}^{2+}$ indicator at $5 \mu \mathrm{M}$ (Molecular Probes, Eugene, OR, USA) for 20 min at room temperature and subsequently washed with the extracellular Hepes-Tyrode solution to remove dye excess. $\left[\mathrm{Ca}^{2+}\right]_{\mathrm{i}}$ transients were elicited by field-stimulating through a pair of platinum electrodes with a 0.2 ms supra-threshold voltage square pulses. Cells were stimulated at $1 \mathrm{~Hz}$ to produce steady-state conditions. A Meta LSM 510 scanning system (Zeiss GmbH, Germany) with a $63 x$ oil immersion objective was used for confocal fluorescence imaging. Fluo-4 was excited at $488 \mathrm{~nm}$ (Argon laser), and the emission intensity was measured at $>510 \mathrm{~nm}$. The digital image was processed using the Matlab platform. The $\mathrm{Ca}^{2+}$ levels were reported as $F / F_{0}$, where $F$ is the maximal fluorescence intensity average measured during the systolic phase of the $\left[\mathrm{Ca}^{2+}\right]_{\mathrm{i}}$ transients, and $\mathrm{F}_{0}$ is the minimal fluorescence intensity average measured between $1 \mathrm{~Hz}$ contractions during the diastolic phase of the $\left[\mathrm{Ca}^{2+}\right]_{i}$ transients. The time to peak of the $\left[\mathrm{Ca}^{2+}\right]_{i}$ transient and time from peak transient to half resting level of $\left[\mathrm{Ca}^{2+}\right]_{i}$ were determined.

The RV samples harvested from the myocardium after enzymatic perfusion were homogenized in a buffer containing $50 \mathrm{mM}$ potassium phosphate (pH 7.0), 0.3 M sucrose, 0.5 mM DTT, 1 mM EDTA (pH 8.0), 0.3 mM PMSF, $10 \mathrm{mM}$ NaF and phosphatase inhibitors cocktail (1:100, Sigma-Aldrich, Saint Louis, MO, USA). Samples were subjected to SDS-PAGE in polyacrylamide gels (6-8\%). The proteins were electrotransferred to nitrocellulose membrane (Amersham Biosciences, USA). The equal loading of samples $(60 \mu \mathrm{g})$ and uniform transfer efficiency were monitored by staining the membrane with $0.3 \%$ Ponceau. Then, the membrane was blocked [5\% nonfat dry milk, $10 \mathrm{mM}$ TrisHCl (pH 7.6), $150 \mathrm{mM} \mathrm{NaCl}$, and $0.1 \%$ Tween 20] for $2 \mathrm{~h}$ at room temperature and incubated with specific antibodies overnight at $4^{\circ} \mathrm{C}$. The primary antibodies (Abcam, USA) were used: polyclonal antibodies for total phospholamban (PLBt, 1:1000), phosphorylated phospholamban at serine $16\left(P_{\text {ser } 16}, 1: 1000\right)$ and sarcoplasmic reticulum $\mathrm{Ca}^{2+}$ ATPase (SERCA2a, 1:2500); monoclonal antibodies for $\mathrm{Na}^{+}$/ $\mathrm{Ca}^{2+}$ exchanger (NCX, 1:1000) and GAPDH (1:2000). Binding of the primary antibody was detected with the use of specific peroxidase-conjugated secondary antibodies (rabbit - 1:2500 or mouse -1:2000) for 1:30 h at room temperature. Immunocomplexes were detected by measuring the chemiluminescence reaction (ECL kit; Amersham, Biosciences, USA) and subsequent densitometric analyses using the ImageJ software. Expression levels of GAPDH were used to normalize the data.

\section{Statistical analysis}

The Kolmogorov-Smirnov test was used to assess data normality. One-way ANOVA for repeated measurements followed by the Tukey post hoc test was used to compare the initial and final values in the three groups. A completely randomized One-way ANOVA with post-hoc testing by Tukey was used to make comparisons between groups. Results are means \pm SEM. The statistical significance level was set at the $5 \%$ level.

\section{RESULTS}

The initial and final BW values of WIS group were higher than those of SHR-C and SHR-T groups. BW increase along the follow up period was significant only in WIS group. The WIS group showed higher values of VW and RVW compared to those of control and trained SHR groups. Hypertension and LIET did not affect the VW/TL ratio, although the SHR-T group showed higher VW/TL ratio when compared to the WIS group. Hypertension increased the RVW/TL ratio as compared to normotensive animals, which suggests a degree of RV hypertrophy in hypertensive rats. LIET did not affect this parameter in SHR-T group.

Resting SAP was higher in SHRs compared to WIS animals. SAP decreased in the SHR-T by the end of LIET when compared to SHR-C group. Initial RHR was higher in SHR-T as compared to WIS group. After LIET the SHR-T group showed a tendency $(P=0.08)$ to decrease the final RHR. After 8 weeks of LIET, the TTF of the SHR-T group was longer than that of WIS and SHR-C groups, respectively. (Table 1)

Hypertension induced a increase in RV cell length (Figure 1A), but did not affect cell width and volume. (Figure 1B, 1C) LIET did not modify RV cell length, width and volume in hypertensive rats. (Figures 1A, 1B, 1C)

\section{Cardiomyocyte contractility and $\left[\mathrm{Ca}^{2+}\right]_{i}$ transients}

Hypertension and LIET did not modify the contractile properties of the RV myocytes in WIS, SHR-C and SHR-T groups. (Figures 2A, 2B, 2C)

Figure 3 shows typical line-scan images recorded from field-stimulated cardiomyocytes that were loaded with the fluorescent $\mathrm{Ca}^{2+}$ indicator fluo 4-AM along with representative records of cardiomyocytes contractions. As shown in Figure 4A, hypertension did not affect $\left[\mathrm{Ca}^{2+}\right]_{i}$ transient amplitude and cell shortening, respectively. LIET increased the $\left[\mathrm{Ca}^{2+}\right]_{\mathrm{i}}$ transient amplitude of RV myocytes from SHR-T group compared to SHR-C and WIS groups (Figure 4A), although it has not affected cell shortening (Figure 2A).

Table 1. Body and ventricular weights, cardiovascular parameters and physical capacity.

\begin{tabular}{c|c|c|c}
\hline & WIS & SHR-C & SHR-T \\
\hline Initial BW (g) & $462 \pm 10^{*}$ & $348 \pm 11$ & $352 \pm 12$ \\
\hline Final BW (g) & $523 \pm 11^{* \S}$ & $379 \pm 14$ & $385 \pm 15$ \\
\hline WW (g) & $2.02 \pm 0.03^{*}$ & $1.85 \pm 0.07$ & $1.82 \pm 0.06$ \\
\hline WW/TL (g/cm) & $0.40 \pm 0.04$ & $0.47 \pm 0.02$ & $0.51 \pm 0.02^{\ddagger}$ \\
\hline RVW (g) & $0.43 \pm 0.03^{*}$ & $0.33 \pm 0.01$ & $0.30 \pm 0.01$ \\
\hline RWW/TL (g/cm) & $0.07 \pm 0.01^{*}$ & $0.11 \pm 0.01$ & $0.10 \pm 0.01$ \\
\hline Initial SAP (mmHg) & $110 \pm 4^{*}$ & $159 \pm 3$ & $158 \pm 2$ \\
\hline Final SAP (mmHg) & $107 \pm 3^{*}$ & $164 \pm 2$ & $152 \pm 4^{+}$ \\
\hline Initial RHR (bpm) & $328 \pm 8$ & $357 \pm 6$ & $369 \pm 10^{\ddagger}$ \\
\hline Final RHR (bpm) & $329 \pm 13$ & $352 \pm 6$ & $343 \pm 9$ \\
\hline TTF (min) & $9.95 \pm 0.63$ & $11.53 \pm 0.85$ & $21.94 \pm 2.32^{\#}$ \\
\hline
\end{tabular}

Data are mean \pm SEM of 8 animals in each group. WIS, Wistar rat control. SHR-C, spontaneously hypertensive rat control. SHR-T, spontaneously hypertensive rat trained. BW, body weight; $\mathrm{WW}$, ventricular weight; $T L$, tibia length; RVM, right ventricular weight; SAP, systolic arterial pressure; RHR, resting heart rate; TTF, total exercise time unti fatigue. *, significantly different from SHR-C and SHR-T. ${ }^{5}$, significantly different from WIS Initial BW. ${ }^{+}$, significantly different from SHR-C. ${ }^{\ddagger}$, significantly different from WIS. ", significantly different from WIS and SHR-C. 


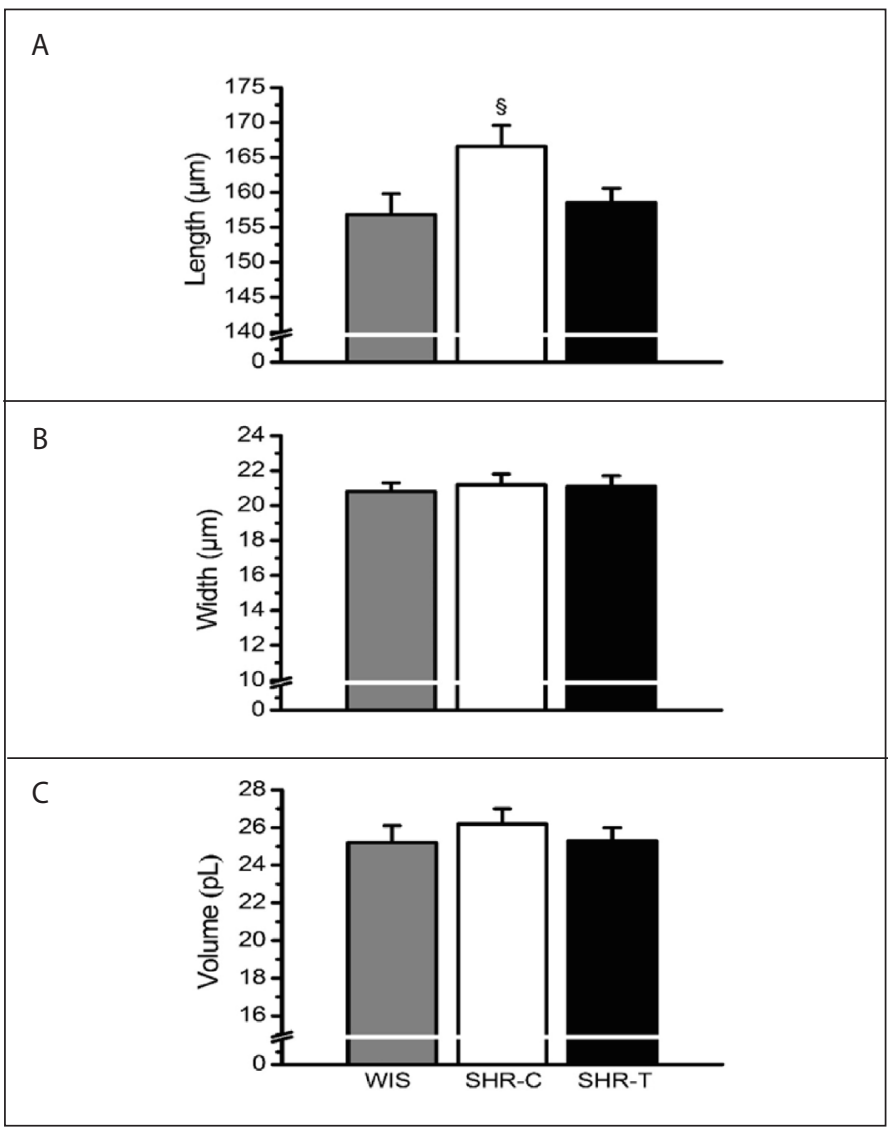

Figure 1. Cardiomyocyte dimensions. WIS, Wistar rat control. SHR-C, spontaneously hypertensive rat control. SHR-T, spontaneously hypertensive rat trained. Data are mean \pm SEM of 130-140 cells in each group. (§), significantly different from WIS.

A

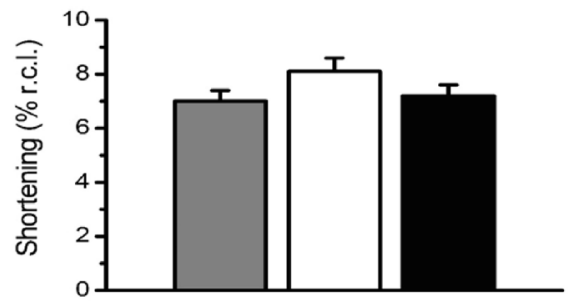

B

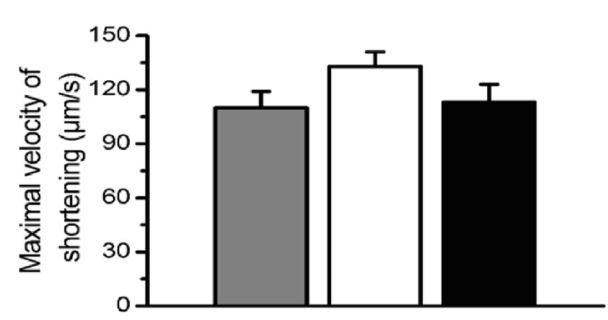

C

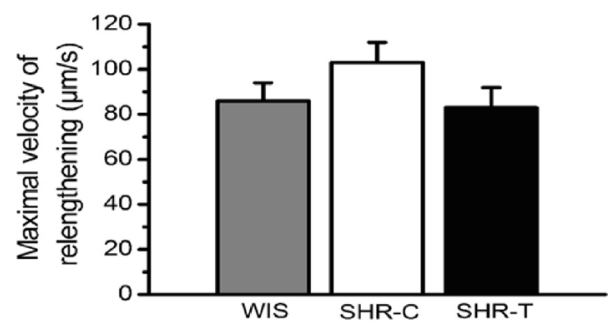

Figure 2. Cardiomyocyte contractile function. WIS, Wistar rat control. SHR-C, spontaneously hypertensive rat control. SHR-T, spontaneously hypertensive rat trained. Data are means \pm SEM of $70-80$ cells in each group.

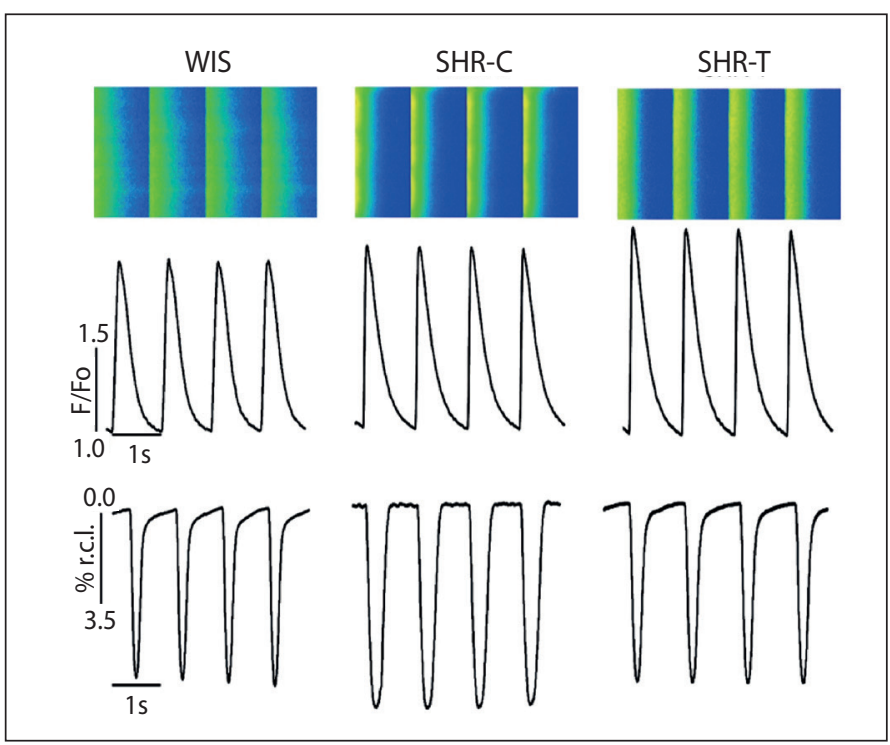

Figure 3. Representative line-scan images recorded from field-stimulated cardiomyocytes loaded with the $\mathrm{Ca} 2+$ indicator fluo 4-AM (5 $\mu \mathrm{M})$ and records of cardiomyocytes contractions. Ca2+ signal is shown as fluorescence ratio (F/F0), with the fluorescence intensity $(F)$ normalized to the intensity at rest before stimulation (F0). Cell shortening as percentage of resting cell length (\% r.c.l.). WIS, Wistar rat control. SHR-C, spontaneously hypertensive rat control. SHR-T, spontaneously hypertensive rat trained.

Notably, no differences were observed in the baseline fluorescence intensity average that was measured between contractions at the diastolic phase of $\left[\mathrm{Ca}^{2+}\right]_{\mathrm{i}}$ transients between the three groups.

The time to peak of $\left[\mathrm{Ca}^{2+}\right]_{i}$ transient (Figure 4B) of RV cells from SHR-C group was higher as compared to those from WIS group. LIET did not modify this parameter in cells from SHR-T group (Figure 4B). Hypertension and LIET did not affect the time from peak to half-resting level of $\left[\mathrm{Ca}^{2+}\right]_{i}$ (Figure 4C). SHR-T group had faster time from peak to half-resting level of $\left[\mathrm{Ca}^{2+}\right]_{i}$ when compared to the WIS group. (Figure 4C)

Neither hypertension nor LIET modified the expression of calcium regulatory proteins in the right ventricle of the WIS, SHR-C and SHR-T groups. (Figures 5A, 5B, 5C e 5D)

\section{DISCUSSION}

We observed that LIET was able to improve the exercise capacity and a tendency to decrease RHR. This result indicates that the exercise training protocol was efficient to produce cardiac adaptations. The resting bradycardia has been considered to be a hallmark of exercise training adaptation in experimental animals. ${ }^{25}$

More important, LIET was efficient in decreasing the SAP in SHR animals. The hypotensive effect of regular exercise in hypertensive individuals is well-documented. ${ }^{1,10,11}$ The exercise intensity influences its pressure-lowering effect, inasmuch as larger reductions are detected at lower exercise training intensities. ${ }^{12,26}$

We also observed that hypertension increased the RVW/TL ratio along with RV myocyte length, but our LIET did not counteract these structural adaptations. It is described that aerobic exercise-induced cardiac hypertrophy is more pronounced in the left ventricle, while ventricular dilation is common in both ventricles. ${ }^{27}$ Our results suggest some degree of hypertrophy in the right ventricle caused by hypertension, which may contribute to chamber enlargement. Pathological LV hypertrophy is associated with cardiac dysfunction, reduced $\left[\mathrm{Ca}^{2+}\right]_{i}$ transients and contractility, increased interstitial fibrosis, decreased vascularization, and re-expression of fetal genes., $.8,28,29$ On the other hand, the right ventricle can be affected by conditions that have been regarded as LV pathologic conditions, like the increased filling pressures during hypertension, ${ }^{18}$ in addition to the increased sympathetic activity in both ventricles. ${ }^{19}$ Our 


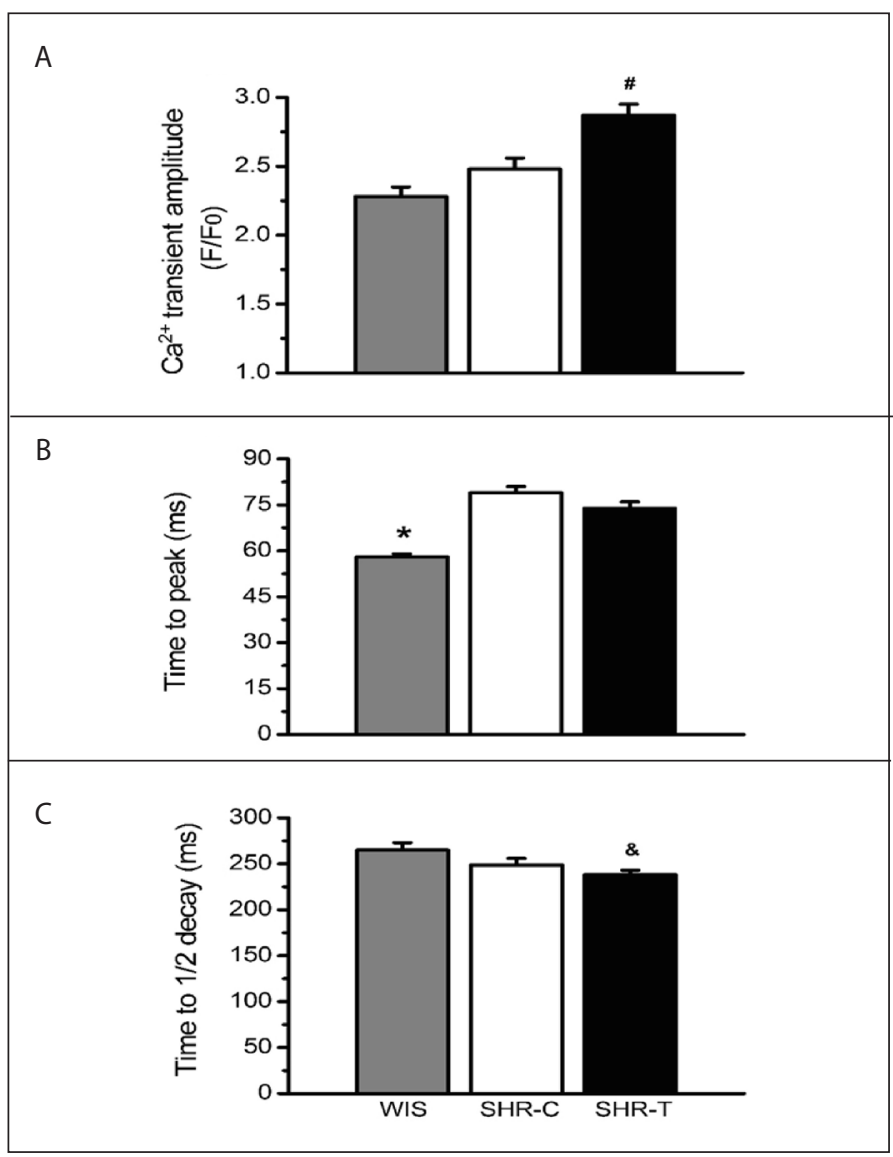

Figure 4. Cardiomyocyte calcium transients. WIS, Wistar rat control. SHR-C, spontaneously hypertensive rat control. SHR-T, spontaneously hypertensive rat trained. Data are mean \pm SEM of 70-80 cells in each group. (\#) significantly different from WIS and SHR-C. $\left(^{*}\right)$ significantly different from SHR-C and SHR-T. (\&) significantly different from WIS.

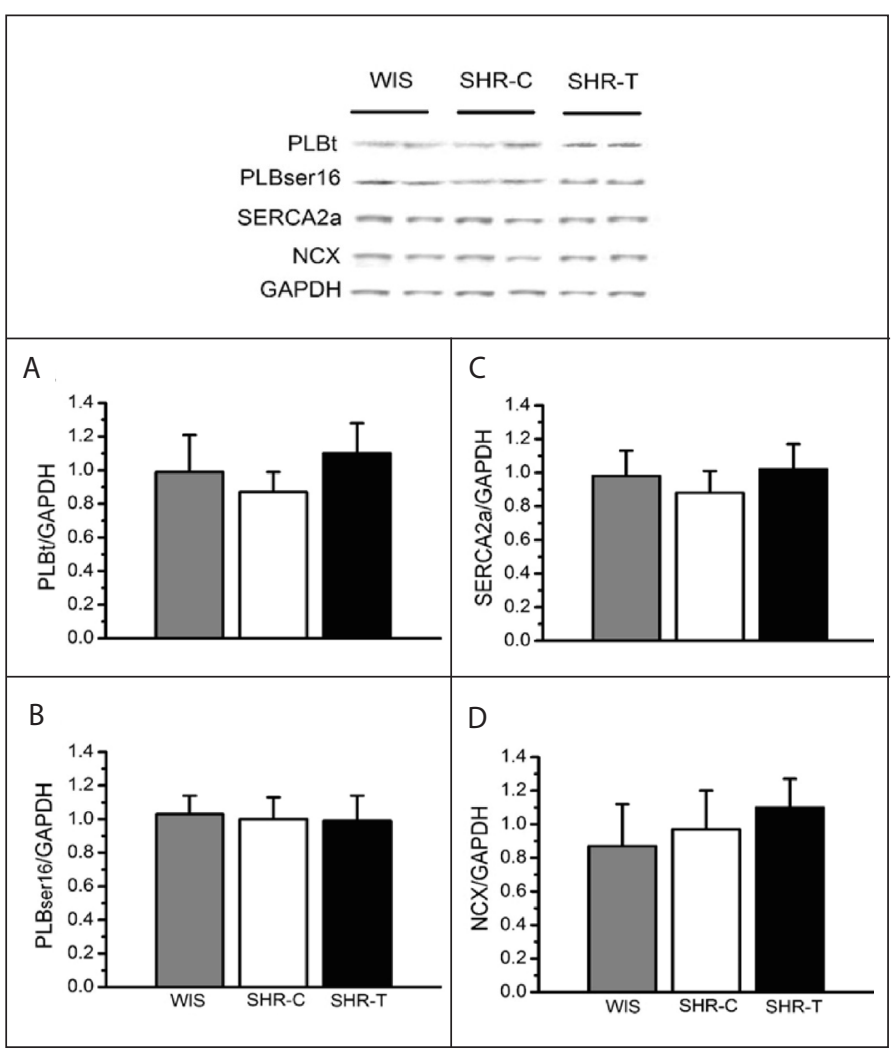

Figure 5. Calcium regulatory proteins expression. WIS, Wistar rat control. SHR-C, spontaneously hypertensive rat control. SHR-T, spontaneously hypertensive rat trained. Data are mean \pm SEM of 6-7 animals in each group. data cannot confirm a established pathological hypertrophy in the RV myocytes from SHRs as we observed only an increase in the time to peak of the $\left[\mathrm{Ca}^{2+}\right]_{i}$ transient. The other parameters of the $\left[\mathrm{Ca}^{2+}\right]_{\mathrm{i}}$ transient were normal, as well as cellular contractility and the expression of the $\left[\mathrm{Ca}^{2+}\right]_{\mathrm{i}}$ transient regulatory proteins, although we did not measure the histological content of this chamber.

Our results demonstrate that LIET induced an increase in the amplitude of RV myocyte $\left[\mathrm{Ca}^{2+}\right]_{i}$ transient in SHR, but did not affect cellular mechanical properties. Because the $\left[\mathrm{Ca}^{2+}\right]$ transient controls cardiomyocyte contractile activity, exercise training-induced changes in cell contractility are mediated by changes in the $\left[\mathrm{Ca}^{2+}\right]_{i}$ transient. However, we did not observe any modifications in RV cell contractility in SHR-T group. Normally, the related changes in the rates of rise and decay of $\left[\mathrm{Ca}^{2+}\right]_{i}$ transient and the rates of contraction and relaxation, indicate that changes in contractility and in the $\left[\mathrm{Ca}^{2+}\right]_{\mathrm{i}}$ transient are closely linked ${ }^{30}$, as we observed in LV myocytes from $\mathrm{SHR}^{8}$ and normotensive rats ${ }^{23}$ submitted to LIET.

The cardiomyocyte contraction-relaxation and the $\left[\mathrm{Ca}^{2+}\right]_{i}$ transient are controlled by proteins that regulate calcium handling. ${ }^{30} \mathrm{We}$ demonstrated here that LIET did not modify the expression of PLBt, $\mathrm{PLB}_{\text {ser16, }}$ SERCA2a and NCX in the RV of SHR-T group. Previously, our group showed that hypertension did not affect the expression of PLBt, PLB ser $16_{1}$ SERCA2a, or NCX in the LV of SHR animals. However, LIET increased the expression of SERCA2a and PLB ${ }_{\text {ser16, }}$ and reduced the PLBt/SERCA2a ratio without changes in NCX and PLBt levels in the LV of both hypertensive and normotensive rats ${ }^{8}$. In normotensive rats, we have already shown that LIET was not capable of modifying these proteins in the RV. ${ }^{23}$

In this study, RV myocytes of SHR demonstrated tiny responses to LIET. We have to consider that RV is connected serially to the LV and thus is obligated to pump the same effective stroke volume. Nevertheless, with a thinner and more compliant wall than the LV, it has a distinct physiology related to the low hydraulic impedance characteristics of the pulmonary vascular bed. The output of left and right ventricles are similar, under normal conditions, but the RV output requires approximately $25 \%$ of stroke work which implicate in less energy cost because of the low pressure pulmonary system and to the unique characteristics of the RV pressure-volume relationship ${ }^{15}$. Is worthy to note that these RV specific characteristics could potentially explain the absence of more pronounced adaptations in response to LIET at the cellular and molecular levels.

Moreover, the absence greater structural and mechanical changes in the RV myocytes from SHR submitted to LIET can be explained by the age of these animals since they were in the compensated phase of cardiac remodeling, where the myocardium of both control and exercised animals are able to cope with exercise and hypertension stresses in a positive way. Another possibility is that structural and mechanical adaptive responses of the RV myocytes of SHR to LIET depend on exercise protocols with longer duration and higher intensity. It is noteworthy that different aerobic exercise types or resistance training may lead to different adaptations.

The analysis of RV structural and mechanical properties at the cellular and molecular levels is important to characterize the functional and morphological remodeling in response to endurance training during hypertension. Advances in the comprehension of such cardiac remodeling is of clinical relevance in the assessment of exercise performance and may help to understand the differences between physiological and pathological forms of RV remodeling. Additional studies are necessary to understand the effects of different types of exercise training on the structure and function of the right ventricle in this model of hypertension. 


\section{CONCLUSION}

The compensation phase of hypertension in SHR leads to mild eccentric hypertrophy in the RV, probably due to increased cell length. Although RV myocyte mechanical properties are not affected by either hypertension or LIET, the time course of the $\left[\mathrm{Ca}^{2+}\right]_{\mathrm{i}}$ transient prolongs in response to hypertension, while LIET increases the amplitude of the $\left[\mathrm{Ca}^{2+}\right]_{i}$ transient. Despite that, neither hypertension nor LIET modify the RV $\mathrm{Ca}^{2+}$ regulatory proteins.
Federal University of Viçosa (UFV) facility. This study was funded by Conselho Nacional de Desenvolvimento Científico e Tecnológico (CNPq), Fundação de Amparo à Pesquisa do Espírito Santo (FAPES/ PRONEX), Fundação de Amparo à Pesquisa do Estado de Minas Gerais (FAPEMIG/PRONEX). L. B. Felix, E. M. Oliveira, A. J. Natali, J. G. Mill are CNPq fellows. M. A. Carneiro-Júnior was the recipient of a doctoral scholarship from CNPq.

\section{ACKNOWLEDGMENTS}

The confocal experiments were done at the Núcleo de Microscopia e Microanálise (NMM) - Centro de Ciências Biológicas e da Saúde -

All authors declare no potential conflict of interest related to this article

AUTHORS' CONTRIBUTIONS: Each author made significant individual contributions to this manuscript MACJ (0000-0001-5354-7913)* TNPG (0000-0002-4001-4429)* J GM (00000002-0987-368X)* and AJN (0000-0002-4927-4024)* were the main contributors in the drafting of the manuscript. MACJ, JFQJ (0000-0002-4441-0752)*, LRD (0000-0002-6042-7757)*, VNL (0000-0001-9914-4722)* and FRD (0000-0002-6043-9256)* conducted the data collection. MACJ, TNPG, JFQJ, LRD, VNL, FRD, LBF (0000-0002-6184-2354)*, EMO (0000-0002-7101$312 X)^{*}, J G M$ and AJN participated in the data analysis. MACJ, JGM and AJN participated actively in the discussion of the results. MACJ, TNPG, JFQJ, LRD, VNL, FRD, LBF, EMO, JGM and AJN participated in the review and approved the final version of the manuscript. ${ }^{*} \mathrm{ORCID}$ (Open Researcher and Contributor ID).

\section{REFERENCES}

1. Chobanian AV, Bakris GL, Black HR, Cushman WC, Green LA, Izzo JL, Jr., et al. The seventh report of the joint national committee on prevention, detection, evaluation, and treatment of high blood pressure: the JNC 7 report. JAMA. 2003;289(19):2560-72

2. Bernardo BC, Weeks KL, Pretorius L, McMullen JR. Molecular distinction between physiological and pathological cardiac hypertrophy: experimental findings and therapeutic strategies. Pharmacol Ther. 2010;128(1):191-227.

3. Doggrell SA, Brown L. Rat models of hypertension, cardiac hypertrophy and failure. Cardiovasc Res. 1998;39(1):89-105.

4. Brooksby P, Levi AJ, Jones JV. Contractile properties of ventricular myocytes isolated from spontaneously hypertensive rat. J Hypertens. 1992;10(6):521-7.

5. McCrossan ZA, Billeter R, White E. Transmural changes in size, contractile and electrical properties of SHR left ventricular myocytes during compensated hypertrophy. Cardiovasc Res. 2004;63(2):283-92.

6. Roman-Campos D, Carneiro-Junior MA, Primola-Gomes TN, Silva KA, Quintao-Junior JF, Gondim AN, et al. Chronic exercise partially restores the transmural heterogeneity of action potential duration in left ventricular myocytes of spontaneous hypertensive rats. Clin Exp Pharmacol Physiol. 2012;39(2):155-7.

7. Carneiro-Junior MA, Peluzio MC, Silva CH, Amorim PR, Silva KA, Souza MO, et al. Exercise training and detraining modify the morphological and mechanical properties of single cardiac myocytes obtained from spontaneously hypertensive rats. Braz J Med Biol Res. 2010;43(11):1042-6.

8. Carneiro-Junior MA, Quintao-Junior JF, Drummond LR, Lavorato VN, Drummond FR, da Cunha DN, et al. The benefits of endurance training in cardiomyocyte function in hypertensive rats are reversed within four weeks of detraining. J Mol Cell Cardiol. 2013;57:119-28.

9. Miyai N, Arita M, Miyashita K, Morioka I, Shiraishi T, Nishio I, et al. Antihypertensive effects of aerobic exercise in middle-aged normotensive men with exaggerated blood pressure response to exercise. Hypertens Res. 2002;25(4):507-14

10. Whelton SP, Chin A, Xin X, He J. Effect of aerobic exercise on blood pressure: a meta-analysis of randomized, controlled trials. Ann Intern Med. 2002;136(7):493-503.

11. Pescatello LS, Franklin BA, Fagard R, Farquhar WB, Kelley GA, Ray CA. American College of Sports Medicine position stand. Exercise and hypertension. Med Sci Sports Exerc. 2004;36(3):533-53.

12. Sun MW, Qian FL, Wang J, Tao T, Guo J, Wang L, et al. Low-intensity voluntary running lowers blood pressure with simultaneous improvement in endothelium-dependent vasodilatation and insulin sensitivity in aged spontaneously hypertensive rats. Hypertens Res. 2008;31(3):543-52.

13. MacDonnell SM, Kubo H, Crabbe DL, Renna BF, Reger PO, Mohara J, et al. Improved myocardial beta-adrenergic responsiveness and signaling with exercise training in hypertension. Circulation. 2005;111(25):3420-8.

14. Libonati JR, Sabri A, Xiao C, Macdonnell SM, Renna BF. Exercise training improves systolic function in hypertensive myocardium. J Appl Physiol. 2011;111(6):1637-43.

15. Vitarelli A, Terzano C. Do we have two hearts? New insights in right ventricular function supported by myocardial imaging echocardiography. Heart Fail Rev. 2010;15(1):39-61.
16. Ghio S, Gavazzi A, Campana C, Inserra C, Klersy C, Sebastiani R, et al. Independent and additive prognostic value of right ventricular systolic function and pulmonary artery pressure in patients with chronic heart failure. J Am Coll Cardiol. 2001;37(1):183-8.

17. Zornoff LA, Skali H, Pfeffer MA, St John Sutton M, Rouleau JL, Lamas GA, et al. Right ventricular dysfunction and risk of heart failure and mortality after myocardial infarction. J Am Coll Cardiol. 2002;39(9):1450-5.

18. La Gerche A, Claessen G. Is exercise good for the right ventricle? Concepts for health and disease. Can J Cardiol. 2015;31(4):502-8.

19. Bertagnolli M, Schenkel PC, Campos C, Mostarda CT, Casarini DE, Bello-Klein A, et al. Exercise training reduces sympathetic modulation on cardiovascular system and cardiac oxidative stress in spontaneously hypertensive rats. Am J Hypertens. 2008;21(11):1188-93.

20. Wisloff U, Loennechen JP, Falck G, Beisvag V, Currie S, Smith G, et al. Increased contractility and calcium sensitivity in cardiac myocytes isolated from endurance trained rats. Cardiovasc Res. 2001;50(3):495-508.

21. Natali AJ, Wilson LA, Peckham M, Turner DL, Harrison SM, White E. Different regional effects of voluntary exercise on the mechanical and electrical properties of rat ventricular myocytes. J Physiol. 2002;541(Pt 3):863-75.

22. Kemi OJ, Ellingsen O, Ceci M, Grimaldi S, Smith GL, Condorelli G, et al. Aerobic interval training enhances cardiomyocyte contractility and $\mathrm{Ca}^{2+}$ cycling by phosphorylation of $\mathrm{CaMKII}$ and Thr-17 of phospholamban. J Mol Cell Cardiol. 2007;43(3):354-61.

23. Carneiro-Junior MA, Primola-Gomes TN, Quintao-Junior JF, Drummond LR, Lavorato VN, Drummond FR, et al. Regional effects of low-intensity endurance training on structural and mechanical properties of rat ventricular myocytes. J Appl Physiol. 2013;115(1):107-15.

24. Satoh H, Delbridge LM, Blatter LA, Bers DM. Surface:volume relationship in cardiac myocytes studied with confocal microscopy and membrane capacitance measurements: species-dependence and developmental effects. Biophys J. 1996;70(3):1494-504.

25. De Angelis K, Wichi RB, Jesus WR, Moreira ED, Morris M, Krieger EM, et al. Exercise training changes autonomic cardiovascular balance in mice. J Appl Physiol. 2004;96(6):2174-8.

26. Véras-Silva AS, Mattos KC, Gava NS, Brum PC, Negrao CE, Krieger EM. Low-intensity exercise training decreases cardiac output and hypertension in spontaneously hypertensive rats. Am J Physiol. 1997;273(6 Pt 2):H2627-31.

27. Weiner RB, Baggish AL. Exercise-induced cardiac remodeling. Prog Cardiovasc Dis. 2012;54(5):380-6.

28. Mill JG, Novaes MA, Galon M, Nogueira JB, Vassallo DV. Comparison of the contractile performance of the hypertrophied myocardium from spontaneous hypertensive rats and normotensive infarcted rats. Can J Physiol Pharmacol. 1998;76(4):387-94.

29. Mill JG, Stefanon I, dos Santos L, Baldo MP. Remodeling in the ischemic heart: the stepwise progression for heart failure. Braz J Med Biol Res. 2011;44(9):890-8

30. Kemi OJ, Wisloff U. Mechanisms of exercise-induced improvements in the contractile apparatus of the mammalian myocardium. Acta Physiol (Oxf). 2010;199(4):425-39. 